\title{
Extra-Hepatic portal venous obstruction with portal biliopathy in infant presenting as neonatal cholestasis: a rare case report and review of literature
}

\author{
Yadav A.K. ${ }^{1}$, Meena R. ${ }^{2}$, Bhavika Y.M. ${ }^{3}$, Guruyayappa R. ${ }^{4}$, Dewan V. ${ }^{5}$ \\ ${ }^{1}$ Dr Ajeet Kumar Yadav, ${ }^{2}$ Dr Ramkesh Meena, ${ }^{3}$ Dr Bhavika YM, ${ }^{4}$ Dr Guruayyappa Ramsingh, ${ }^{5}$ Dr Vivek Dewan, all \\ authors are affiliated with Department of Pediatrics, Dr. RML Hospital, New Delhi, India
}

Address for Correspondence: Dr. Ajeet Kumar Yadav, Department of Pediatrics, Dr. RML Hospital, New Delhi, India, Email: ajeet171lrm@gmail.com

\begin{abstract}
Extra-hepatic portal venous obstruction is most common cause of portal hypertension in children. Apart from variceal formation in gastric and esophageal mucosal layer, it has been postulated that external pressure and or ischemic injury play a role in portal biliopathy. We report an unusual case of a 6 month old infant who presented to us with clinical features suggestive of extra-hepatic biliary atresia; diagnosed as EHPVO with portal biliopathy, managed surgically.
\end{abstract}

Keywords: Extra-hepatic portal obstruction, Jaundice, Portal biliopathy

\section{Introduction}

Extra-hepatic portal venous obstruction (EHPVO) is a blockage to the flow of blood in portal vein before it reaches to the liver. EHPVO is the commonest cause of portal hypertension in children which has commonest presentation of upper gastrointestinal bleed [1-3]. There are strictures and dilatations in entire biliary tract and gall bladder secondary to ischemic and compressive effects of portal cavernoma formed in setting of portal hypertension which presents as clinical features of obstructive jaundice, pruritis, pain abdomen (Portal biliopathy) $[4,5]$. Several studies have reported that 81 $100 \%$ of cases of EHPVO have portal biliopathy (PTB) but only one fifth of them present as jaundice [4,6,610]. We report a case EHPVO with PTB in a 6 month infant which has never been reported in literature [4,1113].

\section{Case Report}

A 6 months, female presented to our hospital with yellowish discoloration of eyes and urine since day $6^{\text {th }}$ of life along with failure to gain weight, progressive abdominal distension and irritability of 3 month's duration. Jaundice had been deepening since onset. There was history of passage of clay colored stool, which was non bulky and foul smelling since $2^{\text {nd }}$ week of life. Abdominal distension was progressive along with poor weight gain. There was no history of hematmesis, malena, itching; antenatal history was uneventful and there was no history of umbilical sepsis or NICU hospitalization. Infant was exclusively breast fed till 2 months of age. There was no history of consanguinity, abortion, stillbirth or similar illness in family. Examination revealed, no dysmorphic facies, with normal fundus, dark yellow sclera and skin with poor muscle bulk without pedal edema or bleeding manifestation. Abdominal examination showed distended abdomen with fullness over right and left hypochondrium. Liver was $6 \mathrm{~cm}$ below right costal margin with span of $9 \mathrm{~cm}$ and firm in consistency. Spleen was $4 \mathrm{~cm}$ below left costal margin. Free fluid was present and bilateral kidneys were not palpable. Cardiovascular, respiratory and central nervous systems were essentially normal.

Manuscript received: $26^{\text {th }}$ November 2016

Reviewed: $04^{\text {th }}$ December 2016

Author Corrected: $12^{\text {th }}$ December 2016

Accepted for Publication: $19^{\text {th }}$ December 2016 
Investigation results were; Hemoglobin- 7.1gm/dl, Total leukocyte count- 13900cell/ mm $\mathrm{m}^{3}$, Polymorphs-34\%, Lymphocytes-58\%, Eosinophils-8\%, Platelet count- 2 lakh/ $\mathrm{mm}^{3}$, Total serum bilirubin- $18 \mathrm{mg} / \mathrm{dl}$ with Direct component$17.3 \mathrm{mg} / \mathrm{dl}$, Aspartate transaminase- $288 \mathrm{U} / \mathrm{L}$, Alanine transaminase- $514 \mathrm{U} / \mathrm{L}$, Alkaline phosphatase- $373 \mathrm{U} / \mathrm{L}$, Prothombin Time (PT)- 24.1(13.5), International normalized ratio (INR)- 2.85, Activated partial thromboplastin time (aPTT)- 49.3(28.7), TORCH- Negative, Blood urea- $15 \mathrm{mg} / \mathrm{dl}$, Serum creatinine- $0.2 \mathrm{mg} / \mathrm{dl}$.

Hepatisis B surface antigen (HBsAg), antibody to hepatitis C, A and E were negative. Upper gastrointestinal endoscopy showed two columns of grade II varices. Ultrasound abdomen revealed hepatosplenomegaly, gross ascites, contracted gallbladder, periportal cuffing with normal intrahepatic biliary radicles and portal vein diameter of $4 \mathrm{~mm}$. Color Doppler study of splenoportal system showed periportal anechoeic structures at porta hepatis. CECT abdomen and CT portovenography showed splenomegaly with dilated tortuous splenic vein and collaterals, findings suggestive of EHPVO. A diagnosis of EHPVO with PTB was made on the basis of Magnetic resonance cholangiopancreatography (MRCP) findings showing tortuous biliary tree with multiple biliary strictures in common hepatic duct, common bile duct and cystic duct. Supportive management was started and urgent referral was made to specialized center for surgical management. Outcome in this case was not known as this patient did not turn-up on follow up.

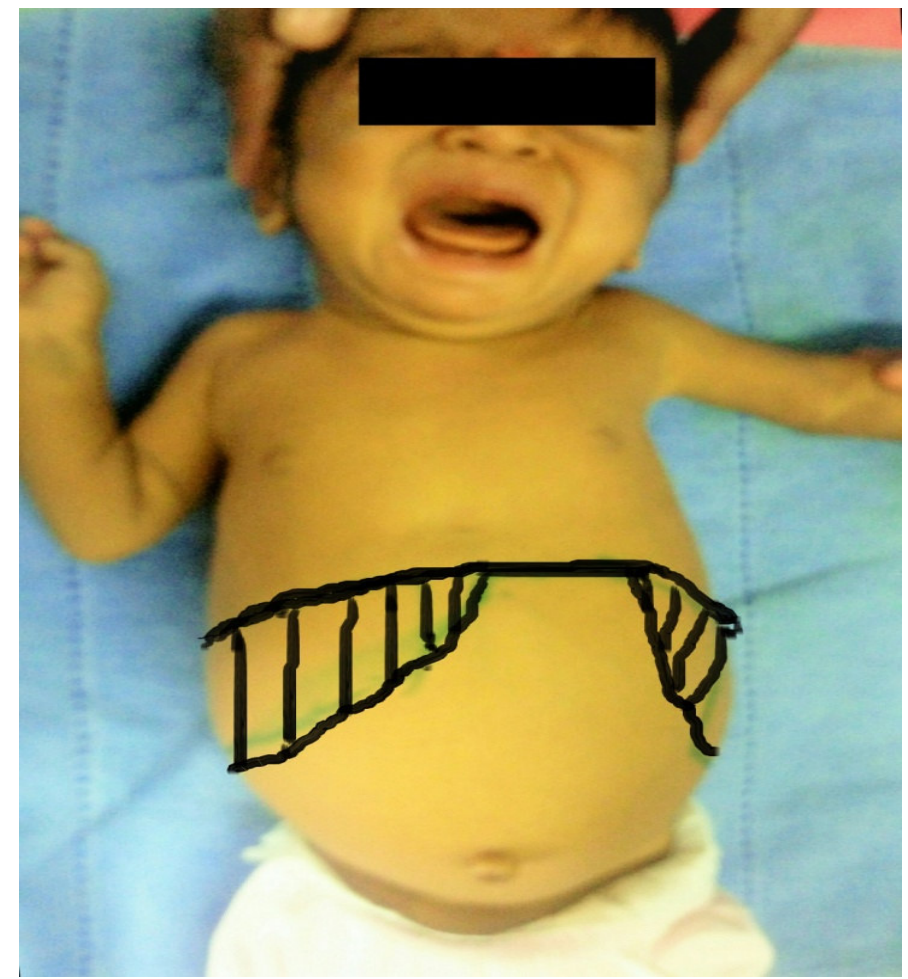

Figure-1: Infant with pigmented skin with Heato-spleenomegaly

\section{Discussion}

The clinical presentation in this 6 month old infant with onset of jaundice since $6^{\text {th }}$ day of life and acholic stool, suggestive of extra-hepatic biliary atresia was later confirmed to be due to PTB as a result of EHPVO. This kind of presentation is unique and has never been reported in the literature, prompted us to report this case. The relationship between EHPVO and jaundice was first time reported by Gibson et al in 1965 [14]. The most common presentation of EHPVO in pediatric age group is well tolerated variceal bleeding and splenomegaly [4]. It is often recognized when a child is being evaluated for jaundice, pruritus, acute cholecystitis-like syndrome and ascites $[7,15,16]$.

Aetiology of EHPVO in children has not been well documented however omphalitis, neonatal umbilical sepsis, intra-abdominal infection, post umbilical catheterization have been linked to development of EHPVO in children [17]. 
Extra-hepatic portal vein obstruction (EHPVO) with portal hypertension leads to abnormality in entire biliary tract including intra-hepatic and extra-hepatic bile ducts, cystic duct and gallbladder changes referred as portal hypertensive biliopathy (PTB) $[4,18]$. Several studies have shown frequency of biliary tract changes in adult patients with EHPVO [6,9,10,19-22], but very less is known about pediatric age group [18]. Although it has been postulated that dilatation of epicholedochal venous plexus of Saint [23] causes fine irregularities in biliary tract and dilatation of paracholedochal venous plexus of Petren [24] causes extrinsic compression over CBD [25]. Post ischemic biliary stricture [25] and encasement of bile duct in solid tumor like cavernoma [21] are other mechanism involved in PTB although mechanism of ischemia in EHPVO remain obscured [25].

In patients with EHPVO, majority of them (80\% to $90 \%$ ) presents with sudden onset hematemesis $[1,2,26]$. The patient under this case report presented to us with deepening jaundice, abdominal distension, failure to gain weight and presence pale stools. The clinical presentation in this case was related to chronic cholestasis, following biliary obstruction secondary to compression of biliary tract with enlarged collateral and ischemic injury to the lumen (PTB).

Findings of PTB and EHPVO can be well described by colour Doppler flow imaging, endoscopic retrograde cholangiopancreaticography (ERCP), CECT and MRI [27-29]. We diagnosed this case with MRCP and CECT portovenography $[30,31]$.

\section{Conclusion}

This unusual age of presentation in this case emphasizes, high index of suspicion and colour Doppler study are helpful tool for the diagnosis of PTB, and however confirmatory diagnosis is established with ERCP or non-invasively by MRCP.

Funding: Nil, Conflict of interest: None initiated, Permission from IRB: Yes

\section{References}

1. Arora NK, Lodha R, Gulati S, Gupta AK, Mathur P, Joshi MS, Arora N, Mitra DK. Indian J Pediatr. 1998 Jul-Aug;65(4):585-91

2. Poddar U, Thapa BR, Rao KL, Singh K. Etiological spectrum of esophageal varices due to portal hypertension in Indian children: is it different from the West? J Gastroenterol Hepatol. 2008 Sep;23(9):1354-7.

3. Poddar U, Thapa BR, Puri P, Girish CS, Vaiphei K, Vasishta RK, Singh K. Non-cirrhotic portal fibrosis in children. Indian J Gastroenterol. 2000 JanMar;19(1):12-3

4. Dhiman RK, Behera A, Chawla YK, Dilawari JB, Suri S. Portal hypertensive biliopathy. Gut. 2007 Jul;56(7):1001-8

5. Ho C, Gunn A, Noordin M. Portal biliopathy. Med J Malaysia. 2014 Oct;69(5):236-7

6. Dilawari JB, Chawla YK. Pseudosclerosing cholangitis in extrahepatic portal venous obstruction. Gut. 1992 Feb;33(2):272-6

7. Sarin SK, Agarwal SR. Extrahepatic portal vein obstruction. Semin Liver Dis. 2002 Feb;22(1):43-58

8. Khuroo MS, Yattoo GN, Zargar SA, Javid G, Dar MY, Khan BA, Boda MI. Biliary abnormalities associated with extrahepatic portal venous obstruction. Hepatology. 1993 May;17(5):807-13

9. Bayraktar Y, Balkanci F, Kayhan B, Ozenç A, Arslan S, Telatar H. Bile duct varices or "pseudocholangiocarcinoma sign" in portal hypertension due to cavernous transformation of the portal vein. Am J Gastroenterol. 1992 Dec;87(12):1801-6

10. Sezgin O, Oğuz D, Altintaş E, Saritaş U, Sahin B. Endoscopic management of biliary obstruction caused by cavernous transformation of the portal vein. Gastrointest Endosc. 2003 Oct;58(4):602-8

11. Hanif FM, Soomro GB, Akhund SN, Luck NH, Laeeq SM, Abbas Z, Hassan SM, Mubarak M. Clinical presentation of extrahepatic portal vein obstruction: 10year experience at a tertiary care hospital in Pakistan. $\mathrm{J}$ Transl Int Med. 2015 Apr-Jun;3(2):74-78

12. Agarwal AK, Sharma D, Singh S, Agarwal S, Girish SP. Portal biliopathy: a study of 39 surgically treated patients. HPB (Oxford). 2011 Jan;13(1):33-9

13. Chattopadhyay S, Nundy S. Portal biliopathy. World J Gastroenterol. 2012 Nov 21;18(43):6177-82

14. GIBSON JB, JOHNSTON GW, FULTON TT, RODGERS HW. EXTRAHEPATIC PORTALVENOUS OBSTRUCTION. Br J Surg. 1965 Feb;52:129-39 
15. Webb LJ, Sherlock S. The aetiology, presentation and natural history of extra-hepatic portal venous obstruction. Q J Med. 1979 Oct;48(192):627-39

16. Rangari M, Gupta R, Jain M, Malhotra V, Sarin SK. Hepatic dysfunction in patients with extrahepatic portal venous obstruction. Liver Int. 2003 Dec;23(6):434-9

17. Narendra K. Arora, Manoja K. Das. Extra Hepatic Portal Venous Obstruction in Children, Portal Hypertension - Causes and Complications, Prof. Dmitry Garbuzenko (Ed.), Available from: http://www.intechopen.com/books/portal-hypertensioncauses-and-complications/extra-hepaticportal- venousobstruction-in-children. 2012th ed. InTech; 2012

18. El-Matary W, Roberts EA, Kim P, Temple M, Cutz E, Ling SC. Portal hypertensive biliopathy: a rare cause of childhood cholestasis. Eur J Pediatr. 2008 Nov;167(11):1339-42

19. Khuroo MS, Yattoo GN, Zargar SA, Javid G, Dar MY, Khan BA, Boda MI. Biliary abnormalities associated with extrahepatic portal venous obstruction. Hepatology. 1993 May;17(5):807-13

20. Malkan GH, Bhatia SJ, Bashir K, Khemani R, Abraham P, Gandhi MS, Radhakrishnan R. Cholangiopathy associated with portal hypertension: diagnostic evaluation and clinical implications. Gastrointest Endosc. 1999 Mar;49(3 Pt 1):344-8

21. Condat B, Vilgrain V, Asselah T, O'Toole D, Rufat P, Zappa M, Moreau R, Valla D. Portal cavernomaassociated cholangiopathy: a clinical and MR cholangiography coupled with MR portography imaging study. Hepatology. 2003 Jun;37(6):1302-8

22. Nagi B, Kochhar R, Bhasin D, Singh K. Cholangiopathy in extrahepatic portal venous obstruction. Radiological appearances. Acta Radiol. 2000 Nov;41(6):612-5

23. SAINT JH. The epicholedochal venous plexus and its importance as a means of identifying the common duct during operations on the extrahepatic biliary tract. Br J Surg. 1961 Mar;48:489-98.

24. Petren T. The veins of the extrahepatic biliary system and their pathologic anatomic significance. Vert Anat Ges. 1932;41:139-143

25. Dhiman RK, Puri P, Chawla Y, Minz M, Bapuraj JR, Gupta S, Nagi B, Suri S. Biliary changes in extrahepatic portal venous obstruction: compression by collaterals or ischemic? Gastrointest Endosc. 1999 Nov;50(5):646-52.

26. Valla DC, Condat B, Lebrec D. Spectrum of portal vein thrombosis in the West. J Gastroenterol Hepatol. 2002 Dec;17 Suppl 3:S224-7.

27. Nunoi H, Hirooka $M$, Ochi H, Koizumi $Y$, Tokumoto Y, Abe M, Tada F, Ikeda Y, Matsuura B, Tanaka H, Tsuda T, Mochizuki T, Hiasa Y, Onji M. Portal biliopathy diagnosed using color Doppler and contrast-enhanced ultrasound. Intern Med. 2013;52(10):1055-9.

28. Gulati G, Pawa S, Chowdhary V, Kumar N, Mittal SK. Colour Doppler flow imaging findings in portal biliopathy. Trop Gastroenterol. 2003 Jul-Sep;24(3):1169.

29. Khuroo MS, Rather AA, Khuroo NS, Khuroo MS. Portal biliopathy. World J Gastroenterol. 2016 Sep 21;22(35):7973-82. doi: 10.3748/wjg.v22.i35.7973.

30. Besa C, Cruz JP, Huete A, Cruz F. Portal biliopathy: a multitechnique imaging approach. Abdom Imaging. 2012 Feb;37(1):83-90. doi: 10.1007/s00261011-9765-2.

31. Magnuson TH, Bender JS, Duncan MD, Ahrendt SA, Harmon JW, Regan F. Utility of magnetic resonance cholangiography in the evaluation of biliary obstruction. J Am Coll Surg. 1999 Jul;189(1):63-71; discussion 71-2.

\section{How to cite this article?}

Yadav A.K., Meena R., Bhavika Y.M., Guruyayappa R., Dewan V. Extra-Hepatic portal venous obstruction with portal biliopathy in infant presenting as neonatal cholestasis: a rare case report and review of literature. J PediatrRes.2016;3(12):889-892.doi:10.17511/ijpr.2016.i12.06. 